\title{
Prevention of adhesion and surface growth of orthopedic implant microbialinfection by surface modification using antibiotics and irradiated hydroxyapatite
}

\author{
Hala A. Farrag, ${ }^{1,}$ HodaH El-Hendawy ${ }^{2}$,Seham, Y.El-Tablawy ${ }^{1}$,Nora F. Hassan. ${ }^{1}$ \\ 1.National Center for Radiation Research and Technology (NCRRT), \\ Department of Drug Radiation Research, Atomic Energy Authority, Egypt, \\ 2. Department of Microbiology, Faculty of Science, Helwan University., Egypt.
}

\begin{abstract}
One of the major drawbacks in the use of biomedical materials is the occurrence of biomaterial-centered infections. After implantation, the host interacts with a biomaterial by forming a conditioning film on its surface and an immune response towards the foreign material. When microorganisms can reach the biomaterial surface they can adhere to it. Adhesion of microorganisms to an implant is mediated by their physico-chemical surface properties and the properties of the biomaterial surface itself. Subsequent surface growth of the microorganisms will lead to a mature biofilm and infection, which is difficult to eradicate by antibiotics.Surface treatment to modify device properties has been used to increase the bio-compatibility and decrease the susceptibility to bacterial adhesion.

In this study a total 52 clinical samples were isolated from implant infection. The microorganism were identified by API system .the susceptibility test was carried out for all isolates to detect multidrug resistant isolates and biofilm formation test was carried out to detect positive slime producing isolates. Antimicrobial activity of irradiated Hydroxyapatite (HAp) was carried out against positive slime producing isolates

The synergistic interaction between irradiated HAp and some antibiotics was carried out to evaluate the effect of irradiated HAp and antibiotics on microbial growth.

The microbial adherence on 316stainless steel chips as biomaterial was detected before and after coating with irradiated HAp and / or antimicrobial agent and it was noticed that the number of adherent strains decreased after coating with irradiated HAp and /or antimicrobial agent. HAp was exposed to gamma irradiation at doses levels 15 and $25 \mathrm{kGy}$ to study the effect of radiation on the antimicrobial activities of HAp. The results revealed that the doses 15 and $25 \mathrm{kGy}$ increased this activity but the $25 \mathrm{KGy}$ showed higher antimicrobial activity.
\end{abstract}

\section{Key Words}

316 Stainless Steel chips, Gamma irradiation, Microbial adherence, Biofilm formation, Hydroxyapatite and Bone infection.

\section{Introduction}

Biomedical devices have become essential parts of the human healthcare system. Over the past two decades, the number of artificial hip and other organ replacements has been used successfully to save lives and to restore quality of life for many people(Griesseret al., 2008).

A wide variety of materials is used for medical purposes. These include ceramic,

Corresponding author : Nora Fayez Hassan email: nora fayez2011@yahoo.com 
glasses, metallic and polymeric biomaterials. Metallic biomaterials that are used include stainless steel, titanium, tantalum, nickel titanium alloys. Medical grade stainless steel (316L SS) is widely used in fracture repair devices and joint replacement components due to the fact that it is a more economical alternative as compared to other metallic biomaterials. ( Saxena and Rout ,2011)

A significant issue in implant surgery and also with short term biomedical devices is bacterial infection. The colonization of surfaces of biomedical devices and implants by bacteria can cause infections that pose a health risk to patients, often require reoperation and replacement of the infected device, and incur considerable healthcare costs. Delayed infections, occurring many weeks or months after surgery, continue to pose a serious problem. It is thought that these late-stage infections are caused not by the act of surgery but by bacterial spores circulating in the vascular system. Spores landing at an incompletely healed wound site may attach to the implant surface, multiply, and form a biofilm that eventually leads to infection. (Griesser et al., 2008). Accordingly, many strategies for reducing the occurrence of infections were used to prevent the initial attachment of bacteria to implant and device surfaces.

Hydroxyapatite $\left(\mathrm{Ca}_{10}(\mathrm{PO} 4)_{6}(\mathrm{OH})_{2}\right)$, abbreviated as HAp, is an inorganic compound, a non-toxic bioactive ceramic and its chemical composition is similar to the composition of bone (Samar et al., 2007). HAp has antibacterial activity against most common gram-positive and gram negative bacteria. (El-Tantawy et al., 2012 and 2013).

Gamma irradiation has been frequently used for sterilization of biomedical materials (Weir,et al.,2004) and can alter different aspects as degradation, hydrophilicity, bioactivity, and sterility (Chu et al., 2002).

Some structural changes in bioceramics such as hydroxyapatite may occur after gamma irradiation like an increase in their enthalpy (Kubisz et al., 2003) and decrease in contact angle with increasing in its biocompatibility.(Sima et al., 2014)

Surface modification of stainless steel is done before its usage in the body for improving its corrosion resistance and bioactivity .Coating of the metallic implants with bioactive HAp leads to a rapid bonding between hydroxyapatite and the surrounding bone tissue. (Saxena and Rout, 2011)

The sol-gel dip coating process can be usefully utilized to synthesize both HAp powders and HAp films under significantly mild conditions. The versatility of the solgel method opens a great opportunity to form thin film coatings in a rather simple process, an alternative to thermal spraying which is currently widely used for biomedical applications(Gupta and Kumar, 2008).

Biomaterial associated infections are dramatic threat to human body. So, this work analyzed the influence of surface modification of 316LSS chipsby coating with $\gamma$ irradiated HAp and/or antimicrobial agents on the extent of relative growth and adhesion ability of some selected strains from implant infection.

\section{Materials and Methods}

\section{Samples, isolation and identification of pathogenic microorganism.}

Clinical samples were taken from fifty two patients with implant infectionfrom microbiological laboratories belonging to Ain -Shams University Hospitals through January to June 2014.All pathogenicisolates were cultivated on nutrient agar medium (NA),nutrient broth (NB) (Oxoid, UK), MacConkey agar No .3(Oxoid, 
UK).Identification was carried out by using the API system (API 20E strips) (The API STAPH)(BioME'RIEUX).

\section{Gamma radiation source}

Cobalt - (60Co) Gamma cell GC220, product of Canada Co.Ltd .located at the National Center for Radiation Research and Technology (NCRRT) Atomic Energy Authority was used for irradiation of HAp and the dose rate was $2.08 \mathrm{kGy} / \mathrm{h}$ at the time of experiments.

\section{Determination of antimicrobial susceptibility patterns}

All pathogenic isolates were subjected to antibiotic sensitivity test using 19different type of antibiotics agents representing different classes and different mode of actions and one antimycotic agent (NS). (Oxoid Ltd, Basingstoke, UK).

This test was done using the antimicrobial disk-agar diffusion procedure, the so-called KirbyBauer disk diffusion method as reported by (Bauer $\boldsymbol{e t}$ al., 1996) and described by National Committee for Clinical Laboratory Standards (NCCLS, 2005) and (Parekh and Chanda, 2006). Sixteen types of antibiotics (Amoxycillin /Clavulainc acid (AMC) ,Imipenem (IPM) ,Cefotaxime (CTX) and Ceftazidime (CAZ), Cefepime (FEP), Amikacin (AK), Gentamicin (CN), Tobramycin (TOB),Doxycycline ( DO ) Clarithromycin (CLR), Azithromycin (AZM), Ciprofloxacin (CIP), Levofloxacin (LEV),Nitrofurantoin (F), Colistin Sulphate (CT),Trimethoprim/ Sulfamethoxazole (SXT)) were used in case of gram negative bacteria. Eighteen types of antibiotics (Amoxycillin/ Clavulainc acid (AMC) ,Imipenem (IPM) ,Cefotaxime (CTX) and Ceftazidime (CAZ), Cefepime (FEP), Vancomycin (VA),Amikacin (AK) , Gentamicin (CN), Tobramycin (TOB),Doxycycline (DO) ,Clindamycin (DA) , Clarithromycin (CLR) , Azithromycin (AZM),Rifampin (RD), Ciprofloxacin (CIP), Levofloxacin (LEV),Nitrofurantoin (F), Trimethoprim/ Sulfamethoxazole (SXT)) were used in case of gram positive bacteria while Nystatin (NS) was used as antimycotic agent .

The diameter of inhibition zone(IZ)was interpreted by referring to standard chart (Oxoid) and the organisms were reported as susceptible(S), intermediate (I), or resistant (R) to the agents that have been tested.

\section{Slime production}

All pathogenic isolates were subjected to qualitative assessment of slime production by the tube method (TM)and Congo Red Agar (CRA) method.

The TM was described by (Christensen $\boldsymbol{e t}$ al., 1982), the tested isolates were inoculated into a glass tube containing $5 \mathrm{ml}$ of trypticase soy broth (TSB, Oxoid), with $1 \%$ glucose and incubated under static conditions at $35^{\circ} \mathrm{C}$ for $24 \mathrm{~h}$.After withdrawal of the contents, the tubes were washed twice with phosphate buffer saline (PBS) (pH 7.3) and dried, then stained with crystal violet $(0.1 \%)$ and excess stain was washed with deionized water.

Slime production was judged to have occurred and adherent growth to be present if a visible continuous stained film lined the inner walls of the tube. The experiments were repeated three times.

The amount of stained biofilm was macroscopically semiquantitated as strong (+++), moderate $(++)$, weak $(+)$ or absent $(0)$. The experiment was performed in triplicate and repeated three times.CRA method was described by Freeman et al., (1989).

CRA medium was prepared with brain heart infusion broth (BHI) (Oxoid, UK) $37 \mathrm{~g} / \mathrm{L}$, sucrose $50 \mathrm{~g} / \mathrm{L}$, agar No. 1 (Oxoid, UK) $10 \mathrm{~g} / \mathrm{L}$ and Congo red indicator (Oxoid, UK) $8 \mathrm{~g} / \mathrm{L}$. First Congo red stain was prepared as a concentrated aqueous solution and autoclaved $\left(121^{\circ} \mathrm{C}\right.$ for $15 \mathrm{~min}$ ) separately from the other medium constituents. Then it was added to the autoclaved brain heart infusion agar with sucrose at $55^{\circ} \mathrm{C}$. CRA plates were inoculated and 
incubated aerobically at $37^{\circ} \mathrm{C}$ for $24 \mathrm{~h}$.Isolates that produced black colonies with dry crystalline consistency were regarded as slime positive, whereas those showing pink colonies were slime negative. The experiment was performed in triplicate and repeated three times.

\section{Adherence assay and quantification of biofilms}

Adherence assay and quantitative determination of biofilm were carried using the tissue culture plate (Christensen et al., 1985). Aliquots $(200 \mu \mathrm{l}) 1.5 \times 108 \mathrm{Cfu} / \mathrm{ml}$ of cell suspension were added to the wells of sterile tissue culture plates, polystyrene, flat bottom tissue culture plate ((Sigma-Aldrich, Costar, USA)) and incubated at $37^{\circ} \mathrm{C}$ for $24 \mathrm{~h}$. The medium and nonadherent cells were removed by washing three times in PBS ( $\mathrm{pH} 7.2)$. Slime and adherent organisms were fixed by incubation for $1 \mathrm{~h}$ at $60^{\circ} \mathrm{c}$ (Baldassarri et al., 1993) and then stained with Hacker crystal violet $(0.1 \% \mathrm{w} / \mathrm{v})$ for $5 \mathrm{~min}$. After washing with water to remove the excess stain, the plates were dried for $30 \mathrm{~min}$ at $37^{\circ} \mathrm{C}$.Then, the optical densities (ODs) of stained adherent biofilm were read with Micro ELISA Auto Reader at wave length 630nm .Adherence measurements were performed in triplicate and the values were then averaged. The isolates were classified based on ODs as weak, moderate or highly adherence according to (Mathur et al., 2006).

\section{Effect of different concentrations of irradiated HAp on some isolates.}

This test was carried out according to the method of Joshi et al., 2009 on slime producer isolates using $(100,150$ and $200 \mathrm{mg})$. Twenty four hour cultures of the selected strains were inoculated in NB, incubated then swabbed over the entire surface of the agar plates. Three wells of $6 \mathrm{~mm}$ diameter were bored in the medium for each plate with the help of sterile corkborer and were filled with $100 \mu$ of the suspension of un-irradiated and irradiated HAp using sterile micropipette. All plates were incubated at $37^{\circ} \mathrm{C}$ for $24 \mathrm{~h}$, followed by measurement of the diameters of IZs. All the experiments were carried out in triplicate, the data were then averaged.

Effect of gamma irradiation on the antimicrobial activity of hydroxyapatite (HAp). This test was carried out according to the method of Joshi $\boldsymbol{e t}$ al., 2009.A definite amount of HAp (Sigma Aldrich, USA) (100 mg) was exposed to $\gamma$ - radiation doses (15 and $25 \mathrm{kGy}$ ) while un-irradiated HAp sample was used as negative control as previously mentioned.

\section{Determination of minimum inhibitory concentrations (MICs) of some selected antimicrobial agents.}

Determination of minimum inhibitory concentrations (MICs) of FEP, CIP, DA and CN was carried out against the selected strains according to (Andrews 2001) and (Parekh and Chanda 2006) and (MIC) of NS was carried out according to Magaldi .et al., (2001).

In a three sterile universals, three stock solutions for each of the selected antibiotics were prepared with different concentrations of $10,000 \mathrm{mg} / 1,1000 \mathrm{mg} / \mathrm{l}$ and $100 \mathrm{mg} / \mathrm{l}$. From the sterile first tube with concentration of $10.000 \mathrm{mg} / \mathrm{l}$ one $\mathrm{ml}$ was added to $9 \mathrm{ml}$ sterile distilled water to give a concentration of $1000 \mathrm{mg} / \mathrm{l}$ in the second tube.

In the third tube $100 \mu \mathrm{l}$ from the initial $10.000 \mathrm{mg} / 1$ solution were added to $9.9 \mathrm{ml}$ sterile distilled water to give a concentration of $100 \mathrm{mg} / \mathrm{l}$, then serial dilutions were prepared

The inoculum used was prepared from a 24-h culture; a suspension was made in a sterile nutrient broth, The turbidity of the suspension was adjusted with a spectrophotometer to obtain a final concentration to match that of a $0.5 \mathrm{McF}$ arland standard .The inoculated agarwas swabbed into the assay plate then wells were cut out of the agar, and $100 \mu$ l of the antimicrobial agent were placed into each well.

The plates were incubated at $35{ }^{\circ} \mathrm{C}$ for $24 \mathrm{~h}$ to determine the diameters of IZs. 


\section{Combination treatment of irradiated HAp and antimicrobial agents againstslime producer pathogens}

The study of synergistic action between irradiated HAp and antibiotics or antifungal against some selected pathogenic strains was carried out according to Bauer et al.,(1996).

Bacterial or yeast cell suspension in NB or sabroud dextrose broth (SDB) was prepared and adjusted $0.5 \mathrm{McFarland}\left(1.5 \times 10^{8} \mathrm{CFU} / \mathrm{ml}\right)$. The microbial suspension was applicated by using sterile cotton swab. Wells of $6 \mathrm{~mm}$ diameter were filled with $50 \mu \mathrm{l}$ of the suspension of the antibiotic (at its MIC) or $50 \mu \mathrm{l}$ of (NS) (at its MIC) and $50 \mu \mathrm{l}$ of irradiated HAp concentration using micropipette.

Plates were left for $45 \mathrm{~min}$ at room temperature. All plates were incubated at $37^{\circ} \mathrm{C}$ for $24 \mathrm{~h}$, followed by the measurement of the diameters of IZs and compared with that of antibiotic, antifungal and irradiated HAp alone.

\section{Surface modification of 316 LSS with irradiated HAp by sol-gel method}

Preparation of irradiated HAp/ polyvinylpyrrolidone (PVP) Composites was carried out according to (Ragu $\boldsymbol{e t}$ al., 2014). To prepare the irradiated HAp/PVP composites, we put a suitable amount of PVP (2gm) in $20 \mathrm{ml}$ double-distilled water with stirring by magnetic stirrer for about $6 \mathrm{~h}$ and then leave the solution for $3 \mathrm{~h}$ at the room temperature to avoid the formation of bubbles. Irradiated HAp solution was slowly added and stirred for $6 \mathrm{~h}$ at the same temperature, a milky white coloration was observed. Finally the mixture was put in dishes in oven at $60^{\circ}$ C.According to Deepak and Uma (2015), the irradiated HAp coating on 316L SS substrates was synthesized by sol-gel method. The pre-sterilized 316L SS samples were dipped into this sol solution at a speed of $10 \mathrm{~mm} / \mathrm{min}$. After dipping once the sample was withdrawn with the same speed as used for dipping to get uniform thickness. Now the coated substrate was dried by immediately transferring into an oven at $70^{\circ} \mathrm{C}$ for 10 minutes.

\section{Detection of antimicrobial activity of coated 316L SS chips on selected slime producer strains.}

The antibacterial effect of $316 \mathrm{~L}$ SS chips coated with irradiated HAp and/or CN was determined by the Kirby- Bauer disk diffusion method as previously mentioned. The diameter ofIZwas measured, including the diameter of the coated stainless steel chips. The experiments was carried out in triplicate, the data were then averaged.

\section{Detection of adherence of selected strains on the surface of 316L SS and coatedwith} irradiated HAp and /antimicrobial agent.

This test was carried out according to Parizzi. et al.,(2004). Sterile clean chip with coated and irradiated HAp and /or antimicrobial agents was immersed in a flask containing $100 \mathrm{ml}$ of BHI, which was previously inoculated with $24 \mathrm{~h}$ suspensions of the selected strains. The flasks were incubated for $24 \mathrm{~h}$ at $37 \mathrm{c}$ and the test was carried out as previously mentioned.

\section{Statistical analysis}

Statistical analysis was employed to detect the effect of gamma irradiation on the antimicrobial activity of hydroxyapatite (HAp) using a software program and analyzed by unpaired two tailed student's t-test (Snedecor and Cochran, 1980). The difference between means were considered to be statistically significant at $\mathrm{p}<0.05$.

\section{Results and Discussion}

\subsection{Results}

Isolation and Identification of microbial isolates 
Fifty two isolates,were isolated from patients(27 males (51.9\%) and 25 females (48\%)),were identified on the bases of their morphological and biochemical characteristics , Forty eight isolates were gram negative bacilli , two belonging to gram positive cocci and two were yeast species. The pathogenic isolates belonging to 6 genera were identified,by using API, sixspecies of pathogenic bacteria and one fungal strain were revealed (Table 1).

These species were E.coli, K.pneumoniae, P. aeruginosa,P.fluorescens, E. cloacae, St.aureus and C. albicans.

Table (1): Th e prevalence genera and species of isolated pathogens

\begin{tabular}{|c||c||c|}
\hline Isolated genera and their Species & Number of isolates & Percent (\%) \\
\hline \hline E.coli & 18 & 34.6 \\
\hline K.pneumoniae & 15 & 28.8 \\
\hline \hline P.species & 6 & 11.53 \\
\hline P.aeruginosa & 4 & 7.69 \\
P.fluorescens & 2 & 3.84 \\
\hline E.cloacae & 9 & 3.84 \\
\hline St.aureus & 2 & 3.84 \\
\hline C.albicans & 2 & \\
\hline \hline Total & 52 & \\
\hline
\end{tabular}

\section{Antimicrobial susceptibility test for all isolated pathogens against different antibiotics.}

Results presented in figures (1-2) showed that some antibiotics affecting the isolated strains It is clear that, the highest percentage of antibiotic resistance of gram negative bacterial isolates was $81 \%$ against CLR, followed by AMC andFEP (74\% and 70\%), respectively, while it was $68 \%$ against CTX and $62 \%$ for AZM. Regarding SXT,F, and CN the percentage of resistance was $58 \%$, and 52\%,50\%,respectively. Followed by CAZ and TOB (47\%), while it was $45 \%$ and $43 \%$ for DOand CIP respectively.In case of CT, the resistance was $35 \%$ followed by LEV and AK (33\% and 25\%), respectively,finally IPM which showed the lowest resistance $8 \%$.( figure 1). The highest percentage of antibiotic resistance of gram positive bacterial isolates was $100 \%$ against CLR, AZM , DO,TOB ,AK and CIP while only one isolate 50\% was resistant to each FEP, CTX , CAZ,VA, IPM ,CN , DA, F, LEV and RD. Meanwhile each of the two isolates was resistant to AMC and SXT. Figure (2).

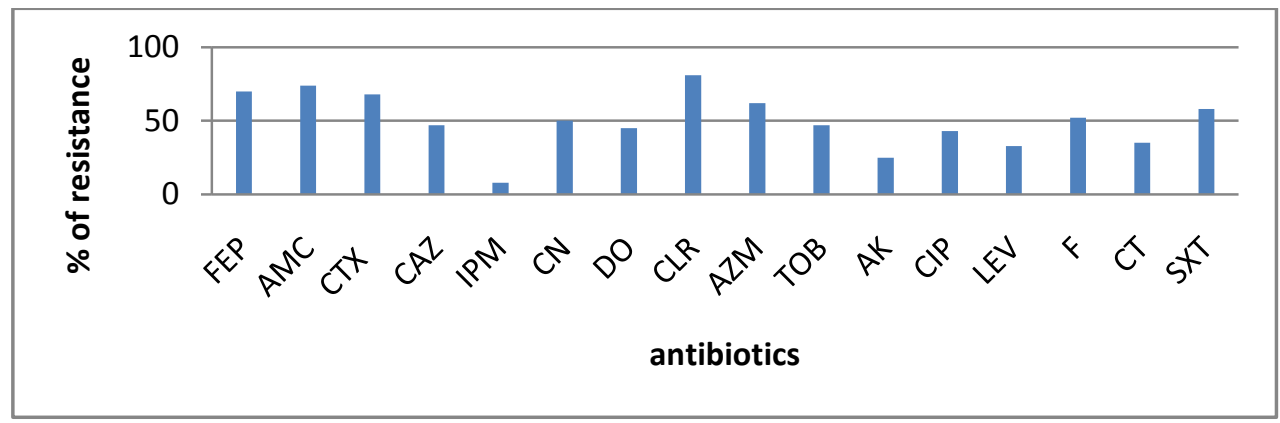

Figure (1): Antimicrobial susceptibility patterns of gram negative bacterialisolates. 


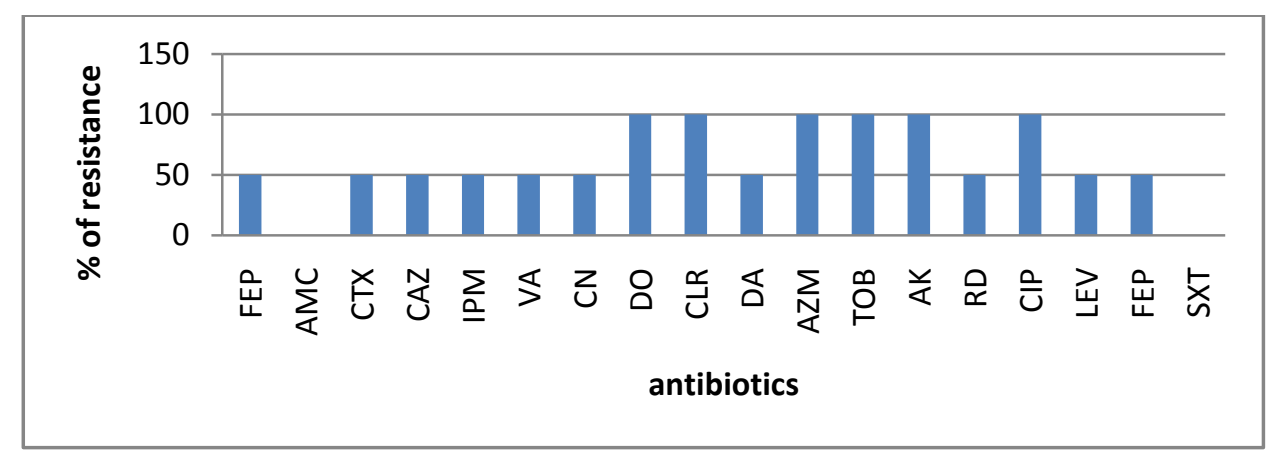

Figure (2):Antimicrobial susceptibility patterns of gram positive bacterial isolates .

\section{Detection of slime productionand quantification of biofilms}

All bacterial pathogens were subjected to a qualitative assessment of slime production by using visual methods; (TM) and (CRA).

It was found that 32(30 bacterial and 2 yeast isolates) out of 52 isolates (61.5\%) were slime positive with variable degrees and $20(38.4 \%)$ were slime negative. Slime production score was carried out in three separate experiments, each performed in duplicate and the results were recorded with three different observers.

Quantitative assessment of slime production was carried out by the spectrophotometric method (quantitative micro method). The results in table (2) revealed that out of the tested pathogens, isolates no. 8, 22, 47 and 52 can strongly produce biofilm while 34 and 14 isolates were moderately and weakly biofilm producers respectively.

Table (2):Slime production and quantitative assessment of adherence of pathogenic isolates.

\begin{tabular}{||c||c|c|c||c|c|}
\hline $\begin{array}{c}\text { Isolate } \\
\text { no. }\end{array}$ & Slime & $\begin{array}{c}\text { Adherence } \\
\text { (ODs) }\end{array}$ & $\begin{array}{c}\text { Isolate } \\
\text { no. }\end{array}$ & Slime & $\begin{array}{c}\text { Adherence } \\
\text { (ODs) }\end{array}$ \\
\hline \hline 1 & $\mathrm{M}$ & 0.177 & 27 & $\mathrm{M}$ & 0.206 \\
\hline 2 & $\mathrm{~W}$ & 0.083 & 28 & $\mathrm{M}$ & 0.223 \\
\hline 3 & $\mathrm{~W}$ & 0.066 & 29 & $\mathrm{M}$ & 0.192 \\
\hline 4 & $\mathrm{M}$ & 0.209 & 30 & $\mathrm{M}$ & 0.167 \\
\hline 5 & $\mathrm{~W}$ & 0.062 & 31 & $\mathrm{M}$ & 0.183 \\
\hline 6 & $\mathrm{~W}$ & 0.074 & 32 & $\mathrm{M}$ & 0.201 \\
\hline 7 & $\mathrm{M}$ & 0.176 & 33 & $\mathrm{M}$ & 0.135 \\
\hline 8 & $\mathrm{~S}$ & 0.263 & 34 & $\mathrm{M}$ & 0.148 \\
\hline 9 & $\mathrm{~W}$ & 0.079 & 35 & $\mathrm{~W}$ & 0.118 \\
\hline 10 & $\mathrm{M}$ & 0.233 & 36 & $\mathrm{~W}$ & 0.058 \\
\hline 11 & $\mathrm{M}$ & 0.217 & 37 & $\mathrm{~W}$ & 0.063 \\
\hline 12 & $\mathrm{M}$ & 0.194 & 38 & $\mathrm{~W}$ & 0.095 \\
\hline 13 & $\mathrm{M}$ & 0.230 & 39 & $\mathrm{~W}$ & 0.065 \\
\hline 14 & $\mathrm{M}$ & 0.143 & 40 & $\mathrm{M}$ & 0.195 \\
\hline 15 & $\mathrm{M}$ & 0.186 & 41 & $\mathrm{M}$ & 0.156 \\
\hline 16 & $\mathrm{M}$ & 0.195 & 42 & $\mathrm{M}$ & 0.213 \\
\hline 17 & $\mathrm{M}$ & 0.210 & 43 & $\mathrm{M}$ & 0.201 \\
\hline 18 & $\mathrm{M}$ & 0.224 & 44 & $\mathrm{~W}$ & 0.087 \\
\hline 19 & $\mathrm{M}$ & 0.152 & 45 & $\mathrm{~W}$ & 0.094 \\
\hline 20 & $\mathrm{~W}$ & 0.059 & 46 & $\mathrm{~W}$ & 0.075 \\
\hline 21 & $\mathrm{M}$ & 0.214 & 47 & $\mathrm{~S}$ & 0.302 \\
\hline 22 & $\mathrm{~S}$ & 0.353 & 48 & $\mathrm{M}$ & 0.182 \\
\hline 23 & $\mathrm{M}$ & 0.217 & 49 & $\mathrm{M}$ & 0.1717 \\
\hline 24 & $\mathrm{M}$ & 0.198 & 50 & $\mathrm{M}$ & 0.231 \\
\hline 25 & $\mathrm{M}$ & 0.201 & 51 & $\mathrm{M}$ & 0.234 \\
\hline 26 & $\mathrm{M}$ & 0.134 & 52 & $\mathrm{~S}$ & 0.251 \\
\hline & & & & \\
\hline
\end{tabular}


W: weakly-adherent (ODs $\leq 0.120)$,M: moderate adherent $(0.120<$ ODs $\leq 0.240)$

S: strongly adherent (ODs > 0.240).

Assessment of antimicrobial activity of different concentrations of irradiated HAp.

This test was carried out to screen the effect of different concentrations $(100,150,200 \mathrm{mg} / \mathrm{ml})$ of irradiated HAp against positive slime clinical isolates. It was found that irradiated HAp has antimicrobial activity against the tested isolates. The results presented in table (3) indicated that by increasing concentration of irradiated HAp, the diameter of IZ increased.

Table (3): Assessment of antimicrobial activity of different concentration s ofirradiated HAp.

\begin{tabular}{|c|c|c|c|c|c|c|c|}
\hline \multicolumn{4}{|c|}{ Inhibition zone (mm) } & \multicolumn{4}{|c|}{ Inhibition zone $(\mathrm{mm})$} \\
\hline \multirow{2}{*}{$\begin{array}{l}\text { Isolate } \\
\text { no. }\end{array}$} & \multicolumn{3}{|c|}{$\begin{array}{l}\text { Concentration of HAp } \\
(\mathrm{mg} / \mathrm{ml})\end{array}$} & \multirow{2}{*}{$\begin{array}{c}\text { Isolate } \\
\text { no. }\end{array}$} & \multicolumn{3}{|c|}{$\begin{array}{c}\text { Concentration of HAp } \\
(\mathrm{mg} / \mathrm{ml})\end{array}$} \\
\hline & 100 & 150 & 200 & & 100 & 150 & 200 \\
\hline 1 & 20 & 22 & 28 & 27 & 15 & 16 & 25 \\
\hline 2 & 20 & 22 & 27 & 28 & 13 & 14 & 16 \\
\hline 3 & 20 & 22 & 30 & 29 & 15 & 22 & 30 \\
\hline 4 & 25 & 30 & 32 & 30 & 20 & 25 & 30 \\
\hline 5 & 15 & 19 & 22 & 31 & 25 & 26 & 34 \\
\hline 6 & 27 & 28 & 32 & 32 & 18 & 21 & 28 \\
\hline 7 & 20 & 26 & 31 & 33 & 12 & 17 & 24 \\
\hline 8 & 17 & 19 & 20 & 34 & 13 & 15 & 18 \\
\hline 9 & 32 & 33 & 37 & 35 & 10 & 15 & 21 \\
\hline 10 & 33 & 34 & 45 & 36 & 13 & 17 & 24 \\
\hline 11 & 21 & 23 & 30 & 37 & 22 & 27 & 35 \\
\hline 12 & 22 & 23 & 32 & 38 & 16 & 20 & 29 \\
\hline 13 & 22 & 30 & 33 & 39 & 16 & 24 & 33 \\
\hline 14 & 16 & 18 & 23 & 40 & 21 & 27 & 35 \\
\hline 15 & 20 & 23 & 28 & 41 & 17 & 22 & 30 \\
\hline 16 & 22 & 28 & 32 & 42 & 20 & 27 & 33 \\
\hline 17 & 15 & 21 & 26 & 43 & 10 & 19 & 25 \\
\hline 18 & 21 & 25 & 30 & 44 & 15 & 21 & 29 \\
\hline 19 & 30 & 32 & 42 & 45 & 12 & 17 & 24 \\
\hline 20 & 30 & 32 & 45 & 46 & 15 & 19 & 25 \\
\hline 21 & 20 & 22 & 23 & 47 & 13 & 15 & 15 \\
\hline 22 & 14 & 17 & 18 & 48 & 20 & 21 & 30 \\
\hline 23 & 15 & 16 & 20 & 49 & 16 & 17 & 20 \\
\hline 24 & 17 & 25 & 35 & 50 & 21 & 22 & 25 \\
\hline 25 & 31 & 32 & 40 & 51 & 11 & 16 & 18 \\
\hline 26 & 25 & 27 & 30 & 52 & 15 & 17 & 19 \\
\hline
\end{tabular}

Effect of gamma irradiation on the antimicrobial activity of HAp against seven selected slime producer strains.

Gamma irradiation is able to affect various structural and biological properties of biomaterials and a dose of $25 \mathrm{kGy}$ of gamma irradiation has been recommended for terminal sterilization of medical products Figure (3) showed the effect of two different doses of gamma irradiation 
(15 and 25kGy) on the antimicrobial activity of HAp against seven selected slime producer strains .It was found that by increasing dose of $\gamma$ irradiation, the antimicrobial activity of HAp increased, if compared to that of control un irradiated samples.

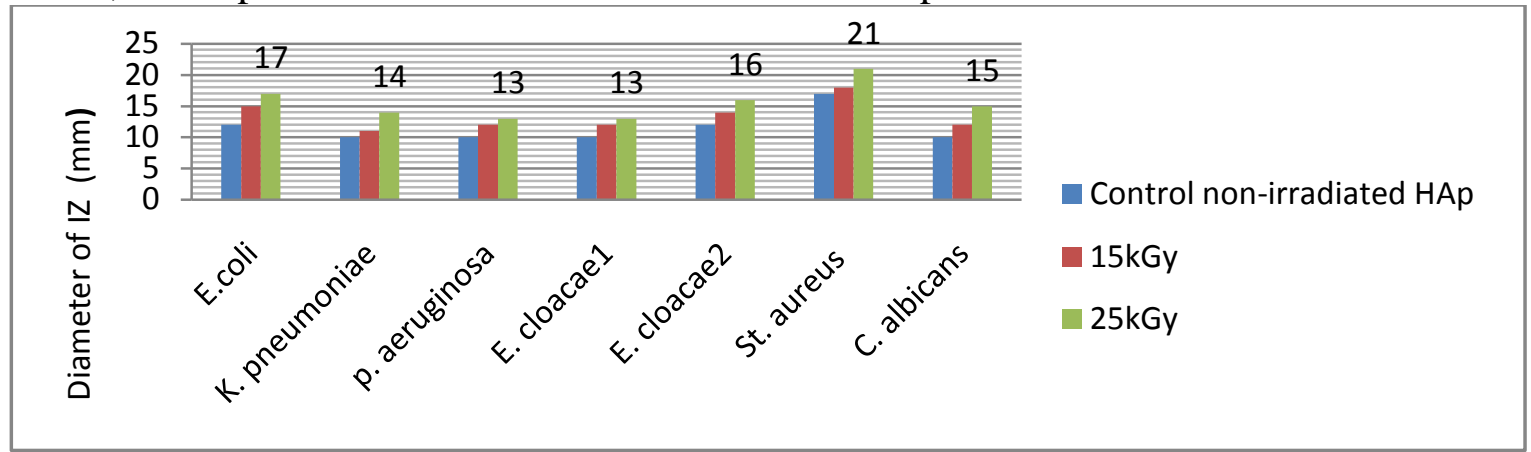

Figure (3): Effect of gamma irradiation on the antimicrobial activity of HAp against seven selected slime producer strains.

\section{Determination of minimum inhibitory concentrations (MIC) of some selected antibiotics and antimycotic agents.}

Minimum inhibitory concentration (MIC) is the lowest concentration of an antimicrobial agent that inhibit the visible growth of a microorganism after an overnight incubation .MICs are used as research tool to confirm resistance and to determine the in vitro activity of new antimicrobials. CN, FEP, CIP and DA were chosen as antibiotics that are usedcommonly in bone infection treatment.

Table (4): Minimum inhibitory concention (MIC) of common antibiotics on the selected slime producer strains.

\begin{tabular}{|c|c|c|c|c|c|c|}
\hline \multirow{2}{*}{$\begin{array}{c}\text { Strain } \\
\text { No. }\end{array}$} & \multirow{2}{*}{$\begin{array}{l}\text { Pathogenic } \\
\text { strain }\end{array}$} & \multicolumn{5}{|c|}{ MIC of antibiotics $(\mathrm{mg} / \mathrm{ml})$} \\
\hline & & FEP & $\mathrm{CN}$ & CIP & DA & NS \\
\hline$\overline{88}$ & E.coli & $\overline{88}$ & $\bar{~} 1$ & 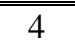 & 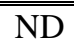 & 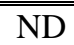 \\
\hline 22 & K. pneumoniae & 16 & 1 & 4 & ND & ND \\
\hline 34 & P. aeruginosa & 128 & 16 & 1 & ND & ND \\
\hline 47 & E. cloacael & 2 & 8 & 2 & ND & ND \\
\hline 49 & E. cloacae 2 & 4 & 4 & 4 & ND & ND \\
\hline 50 & St. aureus & ND* & ND & ND & 0.5 & ND \\
\hline 52 & C.albicans & ND & ND & ND & ND & 12.5 \\
\hline
\end{tabular}

ND*-not detected.

\section{Combination treatment of irradiated HAp and certain antimicrobial agents against some selected slime producer strains}

This study was carried out on seven identified producer strains to elucidate the effect of irradiated HAp in combination with common antimicrobial agents to identify systems which might be used to improve its the efficiency on pathogens. The results were presented in table (5). 
Table (5): Combination treatment of irradiated HAp and some antimicrobial agents against seven selected slime producer strains

\begin{tabular}{|c|c|c|c|c|c|c|c|c|c|c|c|c|}
\hline \multirow[b]{2}{*}{ 丞 } & \multirow[b]{2}{*}{ Microorganism } & \multicolumn{11}{|c|}{ diameter of IZ $(\mathrm{mm})$} \\
\hline & & FEP & $\mathrm{CN}$ & CIP & DA & NS & $\begin{array}{l}\text { HAp } \\
(100 \mathrm{~m} \\
\mathrm{g})\end{array}$ & $\begin{array}{c}\mathrm{HAp}+\mathrm{F} \\
\mathrm{EP}\end{array}$ & $\begin{array}{c}\mathrm{HAp}+ \\
\mathrm{CN}\end{array}$ & $\begin{array}{c}\text { HAp+ } \\
\text { CIP }\end{array}$ & $\begin{array}{c}\text { HAp+ } \\
\text { DA }\end{array}$ & $\begin{array}{l}\text { HAp } \\
+ \text { NS }\end{array}$ \\
\hline 8 & E.coli & 14 & 20 & 21 & ND* & ND & 17 & 22 & 25 & 28 & ND & ND \\
\hline 22 & K. pneumoniae & 14 & 15 & 15 & $\mathrm{ND}$ & ND & 14 & 20 & 24 & 21 & $\mathrm{ND}$ & ND \\
\hline 34 & P.aeruginosa & 16 & 24 & 16 & ND & ND & 20 & 29 & 33 & 31 & $\mathrm{ND}$ & ND \\
\hline 47 & E. cloacae 1 & 18 & 12 & 21 & $\mathrm{ND}$ & ND & 13 & 22 & 30 & 30 & $\mathrm{ND}$ & $\mathrm{ND}$ \\
\hline 49 & E. cloacae 2 & 23 & 13 & 22 & $\mathrm{ND}$ & $\mathrm{ND}$ & 16 & 28 & 35 & 30 & $\mathrm{ND}$ & $\mathrm{ND}$ \\
\hline 50 & St. aureus & 13 & 12 & 16 & 19 & ND & 21 & 28 & 33 & 31 & 33 & $\mathrm{ND}$ \\
\hline 52 & C.albicans & $\mathrm{ND}$ & ND & $\mathrm{ND}$ & $\mathrm{ND}$ & 16 & 15 & ND & ND & ND & ND & 24 \\
\hline
\end{tabular}

ND*: not detected.

Detection of antimicrobial activity of coated 316 L SS chips on selected slime producing strains.

Data presented in Table (6) showed the antimicrobial activity of 316LSS chips coated with irradiated HAp and $\mathrm{CN}$ at its MIC. It was found that after coating, the IZ of all applied strains increased if compared to that coated with irradiated HAp and/ or antimicrobial agents alone.

Table (6): Antimicrobial activity of coated 316L stainless steel chips with IrradiatedHAp and $\mathrm{CN}$ in respect to action of Gentamicin only on certain strains.

\begin{tabular}{|c|c||c|c|c|}
\hline $\begin{array}{c}\text { Strain } \\
\text { No. }\end{array}$ & Pathogenic bacteria & $\begin{array}{c}\text { MIC of } \\
\mathrm{CN}\end{array}$ & $\begin{array}{c}\text { Irradiated } \\
\mathrm{HAp}(100 \\
\mathrm{mg} / \mathrm{ml})\end{array}$ & $\begin{array}{c}\text { Irradiated HAp } \\
+\mathrm{CN} \text { at its MIC }\end{array}$ \\
\hline \hline 8 & E.coli & 20 & 17 & 39 \\
\hline 22 & K.pneumoniae & 15 & 14 & 36 \\
\hline 34 & P. aeruginosa & 14 & 13 & 32 \\
\hline 47 & E. cloacael & 12 & 13 & 36 \\
\hline 49 & E. cloacae 2 & 13 & 16 & 34 \\
\hline 50 & St. aureus & 12 & 21 & 32 \\
\hline 52 & *C.albicans & 16 & 15 & 31 \\
\hline
\end{tabular}

*coating with NS at its MIC

Detection of adherence of selected strains on the surface of 316L SS chips andcoated with irradiated HAp and /or antimicrobial agents.

Table (7) shows the ability of selected strains to adhere on 316 L SS andafter coating with irradiated HAp and /or antimicrobial agents. It was found that the ability of adherence of all strains decreased after coating with irradiated HAp and /or antimicrobial agents. 
Table (7): Detection of adherence of selected strains on $316 \mathrm{~L}$ stainless steel surfacecoated with irradiated HAp and HAp with CN.

\begin{tabular}{|c|c|c|c|c|}
\hline 离 & Pathogenic strain & $\begin{array}{c}\text { Number of } \\
\text { CFU/cm }\end{array}$ & $\begin{array}{c}\text { Number of } \\
\text { CFU/cm }{ }^{2} \text { after } \\
\text { coating with } \\
\text { irradiatedHAp }\end{array}$ & $\begin{array}{c}\text { Number of } \\
\text { CFU/cm }{ }^{2} \text { after } \\
\text { coating with } \\
\text { irradiatedHAp }+\mathrm{CN}\end{array}$ \\
\hline 8 & E.coli & $2.2 \times 10^{5}$ & $1.8 \times 10^{3}$ & $4.0 \times 10^{2}$ \\
\hline 22 & K. pneumoniae & $3.6 \times 10^{5}$ & $2.1 \times 10^{3}$ & $5.5 \times 10^{2}$ \\
\hline 34 & P. aeruginosa & $4.8 \times 10^{5}$ & $3.2 \times 10^{3}$ & $5.5 \times 10^{2}$ \\
\hline 47 & E. cloacael & $4.3 \times 10^{5}$ & $2.0 \times 10^{3}$ & $2.1 \times 10^{2}$ \\
\hline 49 & E. cloacae 2 & $3.8 \times 10^{5}$ & $2.9 \times 10^{3}$ & $2.7 \times 10^{2}$ \\
\hline 50 & St. aureus & $3.1 \times 10^{5}$ & $2.0 \times 10^{3}$ & $4.4 \times 10^{2}$ \\
\hline 52 & ${ }^{*}$ C. albicans & $5.3 \times 10^{5}$ & $4.0 \times 10^{3}$ & $1.3 \times 10^{2}$ \\
\hline
\end{tabular}

*the applied antimycotic agent used with C.albicans was NS

Statistical analysis.

Results in table (8) indicated that there was a significant effect of gamma irradiation at dose $25 \mathrm{kGy}$ on the antimicrobial activity of irradiated HAp against all the tested strains except Staphylococcus aureus, E. cloacae 2and Pseudomonas aeruginosa while gamma irradiation dose (15kGy) affects non-significantly, HAp activity if compared to control non-irradiated sample.

Table (8): Statistical analysis of detection of the effect of gamma irradiation on theantimicrobial activity of hydroxyapatite (HAp)

\begin{tabular}{|c|c|c|c|c|c|c|}
\hline \multirow{3}{*}{$\begin{array}{l}\text { Strain } \\
\text { No. }\end{array}$} & \multirow{3}{*}{ pathogenic strain } & \multicolumn{5}{|c|}{ Diameter of IZ ( $\mathrm{mm})$} \\
\hline & & \multirow{2}{*}{$\begin{array}{c}\text { Control } \\
\text { non- } \\
\text { irradiated }\end{array}$} & \multirow{2}{*}{$\begin{array}{c}\text { HAp }(100 \mathrm{mg}) \\
(15 \mathrm{kGy})\end{array}$} & \multirow{2}{*}{$\begin{array}{c}\mathrm{HAp}(100 \mathrm{mg}) \\
(25 \mathrm{kGy})\end{array}$} & \multicolumn{2}{|c|}{ P-value } \\
\hline & & & & & $15 \mathrm{kGy}$ & $25 \mathrm{kGY}$ \\
\hline 8 & E.coli & 12 & 15 & 17 & 0.046 & 0.026 \\
\hline 22 & K.pneumoniae & 10 & 11 & 14 & 0.758 & 0.028 \\
\hline 34 & P.aeruginosa & 10 & 12 & 13 & 0.456 & 0.19 \\
\hline 47 & E. cloacael & 10 & 12 & 13 & 0.066 & 0.069 \\
\hline 49 & E. cloacae 2 & 12 & 14 & 16 & 0.391 & 0.181 \\
\hline 50 & S. aureus & 17 & 18 & 21 & 0.756 & 0.44 \\
\hline 52 & C.albicans & 10 & 12 & 15 & 0.116 & 0.005 \\
\hline
\end{tabular}

\subsection{Discussion}

Microorganisms can reach a biomaterial implant in several ways at several time points, which determines the properties of the biomaterial surface they will meet. Airborne microorganisms, which can be present in the operating theater, can reach the surface as early as before the implantation (Gottenbos et al., 2000) and interact with a bare substratum surface, not even covered with a conditioning film. Also during insertion of the biomaterial, microorganisms from the skin can be pushed towards the implant surface.

Furthermore, microorganisms from the skin can contaminate the operation wound and reach the implant surface through diffusion, active movement or hematogenous transport. Perioperative contamination is believed to be the most common cause of biomaterial-centered infections ((Maathuis et al., 2005). 
Treatment of an established biomaterial -centered infections is difficult, as the minimum inhibitory concentration (MIC) of antimicrobial agents, necessary to kill the microorganisms, is significantly higher for microorganisms in a biofilm than for planktonic ones.

As antibiotics have little effect on biomaterial-centered infections, the standard procedure for infected orthopedic prostheses is the removal of the implant and implantation of an antibiotic releasing device at the implant site. (Jiang et al., 2010).

In the study 52 clinical samples and specimens were collected from bone wounds, out of them $48(92.3 \%)$ isolates were gram negative bacilli , $2(3.8 \%)$ were gram positive cocci and $2(3.8 \%)$ were yeast. Khosravi et al., (2009) reported that, prevalence of isolated bacteria from orthopedic implant infections was gram positive $33.5 \%$ and gram negative $64.5 \%$. Other authors ,Gomez et al., (2003) found that the incidence rate for gram positive and gram negative bacterial isolates from orthopedic implant infections was $60.6 \%$ and $33.3 \%$ respectively. This difference in results may be due to different nosocomial pathogens present in the operating rooms.

Among the isolated pathogens, E.coli and K.pneumoniae are the most common isolates followed by E.cloacae, P. aeruginosa, P. fluorescens, St.aureus andfinally C.albicans.

Lin et al., (2013) noted that K. pneumoniae was estimated to be higher in long-term acute care hospitals while Pantaet al., 2013is in agreement with our results where they found that E.coli was the major isolates in the different tested clinical samples followed by Klebsiella spp.

Also a study performed by Carvalhoet al., (2012) and Chihara and Segreti, (2010) reported that, gram-negative bacteria, such as P.s aeruginosa and Enterobacteriaceae have grown in importance as causative agents to the increasing number of orthopedic surgeries with the use of implants. Eid and Berbari, (2012) and Arias et al., (2004)found thatC. albicans may be isolated from the talus.

Antimicrobial resistance has become a major medical and public health problem. Most of the common antibiotics as Clindamycin, Cephalosporin's and Gentamicin thatare normally used for treatment of orthopedic infections were ineffective against bacteria alone. Khosravi et al., (2009)

The obtained results in the present study was in complete harmony with the findings shown by Keven et al., (2003) who found that, more than $70 \%$ of gram negative isolates from wound infection, pulmonary infection, and sepsis were sensitive to aminoglycosides, fourth generation Cephalosporin, Quinolones, and Imipenem.Isolates were resistant to first generation Cephalosporin and Amoxycillin\Clavulainc acid.

Bacteria having the ability to produce biofilms lead to long term persistence, promote colonization and increased rate of infections. Biofilm producing clinical isolates tend to survive on implanted medical devices and also on tissue wounds causing cystic fibrosis.(Ercan et al., 2008).

Other authorsRewatkar and Wadher, (2013) showed that $P$. aeruginosa, St. aureus, produces strong biofilm by various methods and these microbes are highly resistant to various antibiotics .Donlan, (2001) found that most of gram positive and gram negative bacteria have the capacity to synthesize biofilm including St. aureus, St. epidermidis, S. viridans, E.coli, E. faecalis, K. pneumoniae, P.mirabilis and P. aeruginosa.

In this study TM and CRA methods revealed that out of 52 isolates $32(61.5 \%)$ were biofilm producers and the remaining of the pathogens cannot produce biofilm. This finding is in a fair agreement with Shyamet al.,(2015).

Quantitative determination of slime production was done by ELISA method. Among 52 producing biofilm isolates, four isolates were detected as strong adherent, 34 as moderate adherent and 14 as weak adherent. Nabajit, (2014) demonstrated that among 100 isolates 
from blood samples, urine sample, others, 36 isolates were detected as strong, 47 as moderate and 17as weak/non biofilm producers.

A similar study performed by Afreenish et al., (2011) showed among 110 isolates from the pus, intravenous and urinary catheter tips, urine and sputum the tissue culture plate detected 25 isolates as strong and 45 as moderate biofilm producers. Bacterial adherence may trigger the process of microbial growth and biofilm formation .Results, in the current study, showed that tested strains have the ability to adhere on 316L SSchips.

The use of synthetic hydroxyapatite (HAp) in biomedical applications is well warranted. It has shown to have an excellent biocompatibility in human tooth and bones. Additionally it has been documented to possess antibacterial potentials. HAp is non-toxic and did not elicit any inflammatory symptoms (Surajitet al., 2011).The current investigation was carried out to screen the antimicrobial activity of HAp against the tested pathogens. The obtained results showed that HAp has antimicrobial activity against all the tested isolates from bone wounds, by increasing its concentration, the diameter of inhibition zone increased. Our results are in agreement with Ragab et al., (2014) who found that hydroxyapatite is active against most common gram-positive and gram negative bacteria making it useful for clinical applications and environmental fields. Also Tin -Oo et al., (2007) demonstrated that the antibacterial property HAp should be used to good advantage as a bioactive biomaterial in dental and maxillofacial applications.

El-Tantawy et al., 2012 and 2013 reported that Gram-positive bacteria (such as St. aureusand St. epidermidis) are less susceptible to Ca ions than Gram-negative bacteria (such as E. coli, K.pneumoniae, $P$. aeruginosa,) due to differences in their membrane structure. Another possible explanation for the antibacterial effect is based on the abrasive surface ordering (i.e. texturing) of HAp due to surface defects and aggregates which contribute to the mechanical damage to the cell membrane of the bacteria. (Ragab et al., 2014)

Nguyen et al., (2007) demonstrated that a dose of $25 \mathrm{kGy}$ of gamma irradiation has been recommended for terminal sterilization of medical products.

The antimicrobial activity of HAp exposed to $\gamma$ - irradiation doses (15 and 25) kGy was investigated. Our results revealed that the irradiated HAp has more antimicrobial activity on the tested strains if compared to non-irradiated samples.

Sima et al., (2014) reported that $\gamma$-irradiation is able to affect various structural and biological properties of biomaterials. They indicated a decrease in alkaline phosphatase activity in irradiated HAp ( 25 and $50 \mathrm{kGy}$ ) which can enhance its application as biomaterial. Thanigaiarulet al., (2013) found that low energy ion beams have also improved wettability, bioactivity, and protein absorption without major structural changes.

Concern is increasing about the emergence of antimicrobial resistance. MIC of Gentamicin for some gram negative bacilli isolates including E. coli, K.pneumoniae, P. aeruginosa and E.cloacae haspreviously been shown to be ranged between $\leq 0.06 \mathrm{mg} \backslash 1$ and $\leq 64 \mathrm{mg} \backslash$ Ling $\boldsymbol{e t}$ al., (2006), Hirakata et al., (2005)

Also Fish et al., (2002) found that, MIC values of Cefepime against Pseudomonas aeruginosa were between $\leq 0.125-\leq 8 \mathrm{mg} / \mathrm{l}$ which the results obtained in the present study.

Surface modification is considered an economical method for improving corrosion resistance and bioactivity of biomaterials. Coating approaches can effectively modify surface properties for bone implants. The sol gel dip-coating process is used mainly for the production of coatings on items This deposition method has the advantage of being capable of producing multiple coatings with a high degree of uniformity up to $1000 \mathrm{~nm}$ thick.Balamurugan et al., (2005) and Harleet al.,(2006) recommended employing HAp coatings on the surface of the metallic implants. Mehdi et al., (2012) demonstrated that Sol- 
gel dip coating method is proved to be a cheap and easy coating deposition method for the metallic biomaterials. Also Deepak and Uma, (2015) demonstrated that HAp coatings have been successfully deposited on 316L SS using sol-gel dip coating technique.

In the current study, we use sol-gel dip coating as a method of surface modification for preventing adherence of pathogens on the applied 316L SS. The obtained results clearly indicate that coating of chips with irradiated HAp and antimicrobial agents inhibit the ability of growth of pathogens and consequentially its ability to produce biofilm. Thanainit et al., (2008) found that antibiotic hydroxyapatite pellets effectively release antibiotics and can inhibit the growth of bacteria causing infection in orthopedics.

Stigtera,(2004) reported that the incorporation efficiency of an antibiotic is strongly related to the presence and number of the carboxylic groups in its chemical structure.Soantibiotics, containing carboxylic groups in their chemical structure were better incorporated than others. Hydroxyapatite contains two types of binding sites, positively charged calcium and negatively charged phosphate groups. The antibiotics interact chemically with calcium and phosphate ions in hydroxyapatite according to their chemical structure. Basic antibiotics containing amino groups might be co-precipitated with phosphate, but this mechanism is less likely. For instance, Gentamicin is basic antibiotic and lack carboxylic groups. It was poorly incorporated and quickly released from the coating. Nystatin is a polyene antibiotic obtained from Streptomyces noursei. The molecular formula for nystatin is $\mathrm{C}_{47} \mathrm{H}_{75} \mathrm{NO}_{17}$; Nystatin is an antibiotic which is both fungistatic and fungicidal in vitro against a wide variety of yeasts and yeast-like fungi, including $C$. albicans. It was observed that nystatin contain carboxylic group so it interacts well with hydroxyapatite and release slowly. Our results confirmed that the synergism between irradiated HAp and the tested antibiotic or NS enhanced the effect of irradiated HAp on the growth of the selected strains.

\section{Conclusion}

Persistent bacterial infections associated with medical implants remain a serious and costly drawback with both temporary and permanent consequences. Clinical observations of implant-associated infections have revealed that the initial adhesion and growth of microorganisms on the surface of an implant may be the most critical event in the development of device-associated infection.

In order to overcome or reduce this problem, surface modification of the biomaterials or devices is a relatively straightforward strategy for creating the desirable surfaces which will decrease the susceptibility to bacterial adhesion .Specific coatings may be applied to a device to receive antimicrobial agents to provide device protection from infection

\section{References}

Afreenish, H.; Javaid, U.; Fatima, K.; Maria, O.; Ali, K. and Muhammad,I. Evaluation of different detection methods of biofilm formation in the clinical isolates. Braz $\mathrm{J}$ Infect Dis Elsevier Editora Ltda.,15(4):305-311(2011).

Andrews, M.J. (2001)Determination of Minimum Inhibitory Concentrations.Journal of Antimicrobial Chemotherapy .48 Suppl. 5-16(2001).

Arias, F.; Mata-Essayag, S.; Landaeta, M.E.; Capriles, C.H.; Pérez, C.; Núñez, M.J.; Carvajal, A. and Silva, M. Candida albicans osteomyelitis: case report and literature review. Int. J. Infect. Dis., 8(5), 307- 314(2004). 
Balamurugan, A.; Kannan, S. and Rajeswari, S. Evaluation of $\mathrm{TiO} 2$ coatings obtained using the sol-gel technique on surgical grade type 316L stainless steel in simulated body fluid, Materials Letters 59, 3138-3143(2005).

Baldassarri, L.; Simpson, W.A.; Donelli, G. and Christensen, G.D.Variable Fixation of Staphylococcal Slime by Different Histochemical Fixatives. European Journal of Clinical Microbiology \& Infectious Diseases; 12:866-868(1993) .

Bauer, A. W.; Kirby, W. M. M.; Sherris, J. C. and Turck, M. Antibiotic Susceptibility Testing By a Standardized Single Disk Method. Am. J. Clin. Pathol. 45: 493-496(1996).

Carvalho, V.C.; Oliveira, P.R.D.; Dal-Paz, K.; De Paula, A.P.; Félix, C.S.F. and Lima, L.L.M.Gram-negative osteomyelitis: clinical and microbiological profile. Braz. J. Infect. Dis.,16, (1), p.63-67(2012).

Chihara, S. and Segreti, J. Osteomyelitis. Dis. Mon., 56 (1) p.5-31 (2010).

Christensen, G.D.; Simpson .W.A.; Bisno, A.L. and Beachey, E.H. Adherence of Slime Producing Strains of Staphylococcus Epidermidis to Smooth Surfaces. Infect Immun37:318-26(1982).

Christensen, G.D.; Simpson, W.A.; Baddour, L.M.; Barrett, F.F. and Melton, D.M. Adherence of Coagulase Negative Staphylococci to Plastic Tissue Cultures: A Quantitative Model for the Adherence of Staphylococci to Medical Devices. J Clin Microbiology; 22:996- 1006(1985).

Chu, P. K.; Chen, J. Y. ; Wang, L.P. and Huang, N. Plasma-surface modification of biomaterials,"Materials Science and Engineering R: Reports, 36, (5-6), pp. 143206(2002).

Deepak ,N. and Uma ,B. Effect of number of coatings on structure, mechanical properties and corrosion behaviour of HA coating on 316L stainless steel Journal of Chemical and Pharmaceutical Research, 7(4):1018-1023(2015).

Donlan ,R.M.Biofilms and device-associated infections. Emerg Infect Dis; 7(2): 27781(2001).

Eid, A.J. and Berbari, E.F. Osteomyelitis: a review of pathophysiology, diagnostic modalities and therapeutic options. J. Med. Liban.60 (1), p.51-60(2012).

Ercan, P.; Semih, O.; Umit, K.; Gamze,S.; Caglar, C. and Bekir T. Demonstration of Bacterial Biofilms in Chronic Otitis Media. The Mediterranean Journal of Otology, 4:64- 68(2008).

El-Tantawy,F.; Al-Hazmi,F.; Alnowaiser,F.; Al-Ghamdi, A. A.; Attieh .A.; Al-Ghamdi, M.M. and Al-Tuwirqi,A. R. M. A new large - Scale synthesis ofmagnesium oxide nanowires: Structural and antibacterial properties, Superlattices and Microstructures, 52, 200-209(2012).

El-Tantawy,F.; Gary, W. B; El-Shazly, M. D. ; Al-Hazmi,F. A. and Al-Ghamdi,A.A. Rapid fabrication of nanostructured magnesium hydroxide and hydromagnesite via microwave-assisted technique, Powder Technology, 234, 26-31(2013) .

Fish, D. N.; Choi, M. K. and Jung, R. Synergic activity of cephalosporines plus flouroquinolones against Pseudomonas aeruginosa with resistance to one or both drugs.Journal of Antimicrobial Chemotherapy.50: 1045-1049(2002).

Freeman, J.; Falkiner, F.R. and Keane, C.T.New Method for Detecting Slime Production by Coagulase Negative Staphylococci.J Clin Pathol; 42:872-4(1989).

Gomez, J.; Rodriguez, M.; Banos, V.; Martinez L.andClaver ,M.A. Orthopedic implant infection: Prognostic factors and influence of long-term antibiotic treatment on evolution. Prospective study, 1992-1999. Enferm. Infect. Microbiol.Clin.,21: 232236(2003). 
Gottenbos, B.; Van der Mei, H.C. and Busscher, H.J. Initial adhesion and surface growth of Staphylococcus epidermidis and Pseudomonas aeruginosa on biomedical polymers, J Biomed Mater Res 50: 208-214(2000).

Griesser, H.; Ys, H.; Ndi, C.; Britcher, L.; Vasilev, K.; Jasieniak, M.;Griesser, S. and Semple, S. Combating Infections at Biomedical Implants and Devices by Antibacterial Coatings chemistry in Australia 75 (10)(2008) .

Gupta, R. and Kumar, A.Bioactive materials for biomedical applications using sol-gel technology.Biomed Mater.Epub, ;3(3): 034005(2008).

Harle, J.; Kim, H.W.; Mordan, N.; Knowles, J.C.andSalih, V. Initial responses of human osteoblasts to sol-gel modified titanium with hydroxyapatite and titaniacomposition, ActaBiomaterialia, 2, 547-556(2006).

Hirakata, Y.; Matsuda, Y.; Miyazaki, S.; Kamihira, S.; Kwakami,Y.; Miyazawa, Y.; Ono, N.; Kohno, S. and Sentry ,A. P.P. Regional variation in the prevalence of extended spectrum betalactamase- producing clinical isolates in the Asia-Pacific region (SENTRY 1998-2002). Digan.Microbiol. Infect. Dis., 52: 323-329(2005).

Jiang ,P.J.; Patel ,S.; Gbureck, U.; Caley, R. and Grover, L.M.Comparing the efficacy of three bioceramic matrices for the release of vancomycin hydrochloride.J Biomed Mater Res B ApplBiomater. 93(1):51-8. doi: 10.1002/jbm.b.31557(2010).

Joshi, P.; Chakraborti, S. and Chakrabarti, P. Role of Surface Adsorbed Anionic Species in Antibacterial Activity of $\mathrm{ZnO}$ Quantum Dots against Escherichia coli. JNN;9: 64276433(2009).

Keven, K.; Ates, K. and Sever, M. S.Infections complications after mass disasters: The Marmara earthquake experience. Scand J. Infect. Dis., 35: 110-113(2003).

Khosravi, A.D.; Ahmadi, F.;Salmanzadeh ,S.;Dashtbozorg,A. and AbasiMontazeri, E. Study of bacteria isolated from orthopedic implant infections and their antimicrobial susceptibility pattern .research journal of microbiology, 4(4):158-163,ISSN18164935(2009).

Kubisz, L. , Mielcarek, S. and Jaroszyk, F. Changes in thermal and electrical properties of bone as a result of 1 MGy-dose $\gamma$ - irradiation, International Journal of Biological Macromolecules, 33(1)-3, pp. 89-93(2003).

Ling, T. K.; Xiong, J.; Yu, Y.; Lee, C. C.; Ye, H. and Hawkey, P. M. Multicenter Antimicrobial susceptibility survey of gram negative bacteria isolated from patients with community acquired infections in the Pople's Republic of China. Antimicrobial Agents and Chemotherapy, 50(1): 374-378(2006).

Lin, M.Y.; Lyles-Banks, R.D.; Lolans, K.; Hines, D.W.; Spear, J.B.; Petrak, R.; Trick, W.E.; Weinstein, R.A. and Hayden, M.K. Centers for Disease Control and Prevention Epicenters Program. The importance of long-term acute care hospitals in the regional epidemiology of Klebsiellapneumoniaecarbapenemase-producing Enterobacteriaceae.Clin. Infect. Dis. 57, 1246-1252(2013).

Maathuis, P. G.; Neut, D.; Busscher, H. J.; van der Mei, H. C. and van Horn, J. R.Perioperative Contamination in Primary Total Hip Arthroplasty.Clinical Orthopaedics and Related Research .433 - Issue:pp 136-139(2005).

Magaldi, S.; Mata, S. and Hartung, C. In Vitro Susceptibility to Fluconazole of Candida Spp. Isolates Comparing Three Different Methods. J Mycol Med; 11:123—6(2001).

Mathur, T., Singhal, S., Khan, S., Upadhyay, D.J., Fatma, T. and Rattan, A. Detection of Biofilm Formation among the Clinical Isolates of Staphylococci: An Evaluation of Three Different Screening Methods. Indian J Med Microbial; 24(1):25-9(2006).

Mehdi, M. A.; Rabi'atuladawiyah, J. and Jamaliah, I. Comparative Study On Bioactive Coating Of Ti-6al-4v alloy and $316 \mathrm{~L}$ Stainless Steel association of Metallurgical Engineers of Serbia Metall. Mater. Eng. 18 (2) P. 145-158(2012). 
Nabajit, D.Comparison of Tissue Culture plate method, Tube Method and Congo Red Agar Method for the detection of biofilm formation by Coagulase Negative Staphylococcus isolated from Non-clinical Isolates Int.J.Curr.Microbiol.App.Sci (3(10) 810-815(2014).

National Committee for Clinical Laboratory Standards.Performance Standards for Antimicrobial Susceptibility Testing; 15th Informational Supplement (M100-S15), National Committee for Clinical Laboratory Standards, Wayne, PA(2005)

Nguyen, H.; Morgan, D.A.F. and Forwood, M.R. Sterilization of allograft bone: is $25 \mathrm{kGy}$ the gold standard for gamma irradiation? Cell Tissue Bank.;pp.8:81-9(2007).

Panta , K.; Ghimire, P.; Rai, S. K.; Mukhiya, R. K.; Singh, R. N. and Rai , G. Antibiogram typing of gram negative isolates in different clinical samples of a tertiary hospital. Asian J of Pharmaeutical and Clinical Research.6:153-156(2013).

Parekh, J. and Chanda, S. In-Vitro Antimicrobial Activities of Extracts of Launaea Procumbens Roxb.(Labiateae), Vitis Vinifera L. (Vitaceae) and Cyperus Rotundus L. (Cyperaceae). African Journal of Biomedical Research (Ibadan Biomedical Communications Group, 9(2):89-93(2006).

Parizzi, S. Q. F., Silvânia, Q. F. P.; Nélio, J. D. A.; Cleuber, A. D. S.S.; Nilda, D. F. F. S. and Eldo, A. M. D. S. Brazilian Archives of Biology and Technology47(1) pp. 77-83, ISSN 1516-8913(2004).

Ragab, H. S.; Ibrahim, F. A.; Abdallah, F.; Attieh, A. Al-Ghamdi; Farid ,El-Tantawy; Neyara ,R. and Yakuphanoglu, F. Synthesis and In Vitro Antibacterial Properties of Hydroxyapatite Nanoparticles Journal of Pharmacy and Biological Sciences (IOSRJPBS) e-ISSN: 2278-3008, p-ISSN: 2319-7676. 9(1), Issue 1 ..PP 77-85(2014).

Ragu, A., Senthilarasan, K. and Sakthivel, P. Synthesis and Characterization of Nano Hydroxyapatite with Poly Vinyl Pyrrolidone Nano Composite for Bone Tissue Regeneration Int. Journal ofEngineering Research and Applications ISSN: 2248-9622, 4 (2),pp.50-54(2014).

Rewatkar, A. R. and Wadher, B. J. Staphylococcus aureus and Pseudomonas aeruginosaBiofilm formation MethodsJournal of Pharmacy and Biological Sciences 8( 5), PP 3640(2013)..

Samar, J. K.; Abhilasha, B.; Himesh, A. B. Nanocrystalline calcium phosphate ceramics in biomedical engineering. Materials Science and Engineering C 27 -441-449(2007).

Saxena, A. and Rout, A. the study of hydroxyapatite and hydroxyapatite-chitosan composite coatings on stainless steel by electrophoretic deposition method,Engineering and Technology > Department of Biotechnology and Medical Engineering,2560(2011).

Shyam, K. M. ; Prashant, B. ; Om ,B. ; Keshab ,P.; Bharat, M. P. and Basista ,P. R. Detection of Biofilm Production and Antibiotic Resistance Pattern in Clinical Isolates from Indwelling Medical Devices; Curr Microbial 70:128-134 DOI 10.1007/s00284014-0694-5(2015).

Sima ,S.; Farhood ,N.; Abbas,M.; Tabassom ,H.; Masoumeh ,H. N.; Batool ,k. and Seyyed ,M. F. Effect of Gamma Irradiation on Structural and Biological Properties of a PLGA-PEGHydroxyapatiteComposite 偃e Scientific World Journal , Article ID,420616, ,pp.9(2014).

Snedecor, W.G. and Cochran,G.W.Statistical Methods,7 th ed.,Iowa state University,Ams.,Iowa,USA(1980).

Stigtera, M.; Bezemera, J.; de Grootb, K. andLayrollec,P. Incorporation of different antibiotics into carbonated hydroxyapatite coatings on titanium implants, release and antibiotic efficacy. 99(1), 14 .pp. 127-137(2004). 
Surajit,M.; Debabrata ,K.; Someswar ,D.; Debabrata B. andChidambaram,S.Indigenous hydroxyapatite coated and bioactive glass coated titanium dental implant system Fabrication and application in humans ,J Indian SocPeriodontol.; 15(3): pp.215220(2011).

Thanigaiarul,K.; Elayaraja, K.; Magudapathy, P. ;Kamachi, M.U.; Nair,K.G.M.; Sudarshan,M.; Krishna,J.B.M.; Chakraborty,A. and Narayana, K. S. Surface modification of nanocrystalline calcium phosphate bioceramics by low energy nitrogen ion implantation, Ceramics International, 39(3), pp. 3027-3034(2013).

Thanainit ,C. M.D.; Panya, S. M.D.; Suriya, L. M.D. and Pipat ,O.M.D. In Vitro Antimicrobial Activity of Phramongkutklao Hydroxyapatite Antibiotic Pellet Med Assoc Thai; 91 (12): 1868-72(2008).

Tin-Oo ,M.M.;Gopalakrishnan ,V.; Samsuddin, A.R.; Al Salihi ,K.A. and Shamsuria ,O. Antibacterial property of locally produced hydroxyapatite Archives of Orofacial Sciences . 2, 41-44(2007).

Weir, N.A.; Buchanan, F.J.; Orr, J.F.; Farrar, D.F. and Boyd, A. Processing, annealing and sterilization of poly-L-lactide.Biomaterials.25:3939-49(2004). 


\section{الملخص باللغة العربية}

منع الالتصاق والنمو السطحي للعدوي الميكروبية علي الطعم العظمي بواسطه تعديل السطح باستخدام المضادات الحيوية وهيدروكسي ابيتايت المشعع الليطع

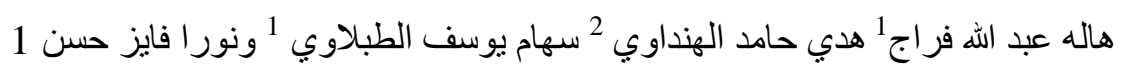

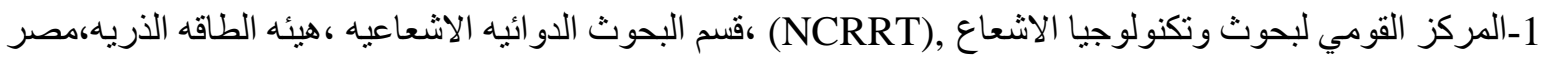

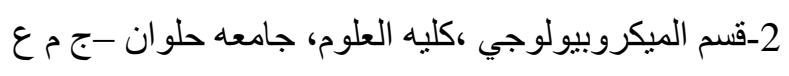

ان واحدة من العو ائق الرئيسية في استخدام المو اد الطبية الحيوية هي حدوث الالتهابات التي تتو اجد على المو اد الحيويا.

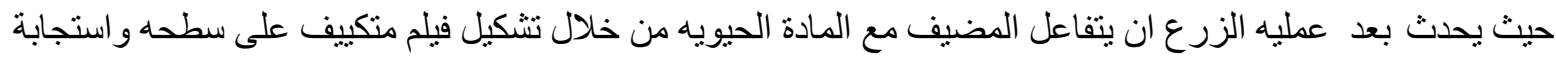

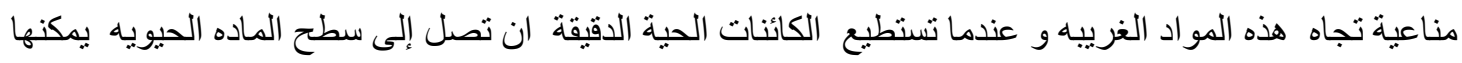

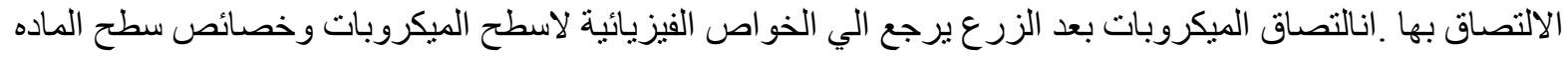

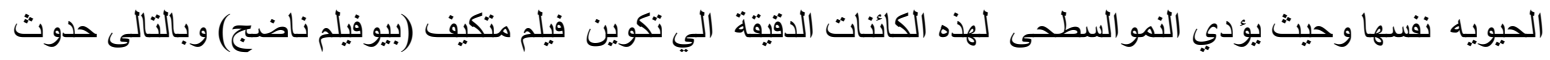

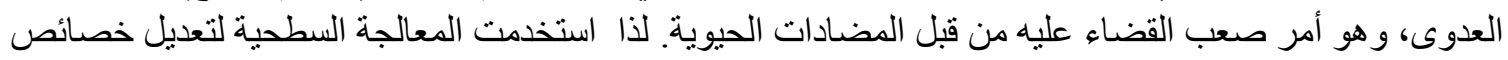

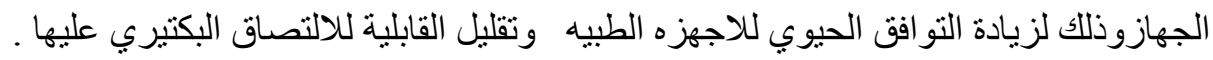

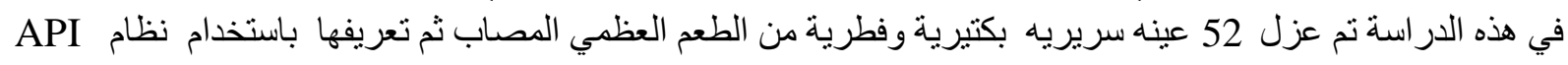

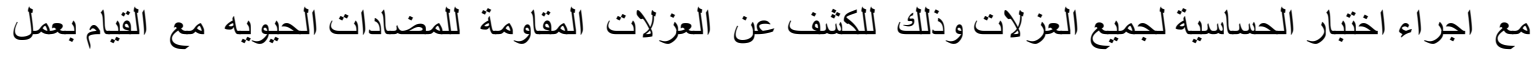

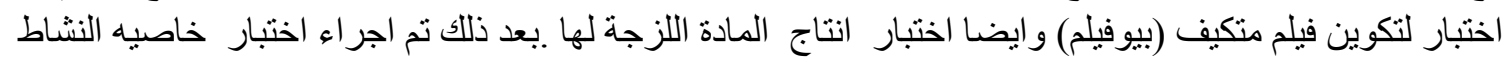

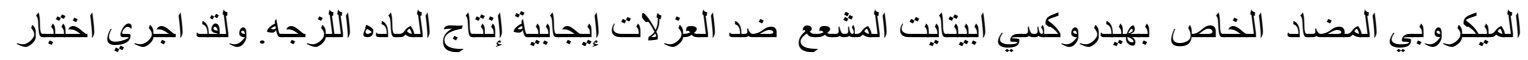

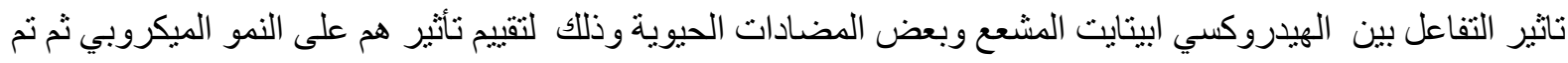

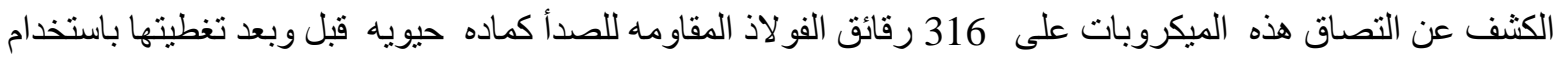

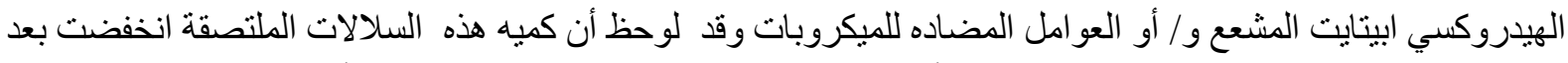

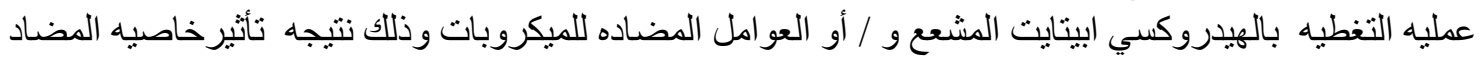

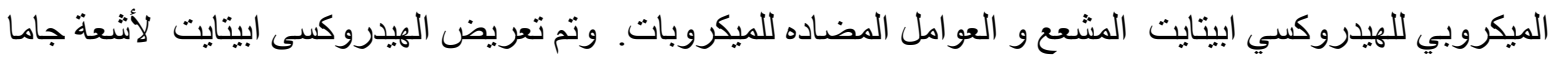

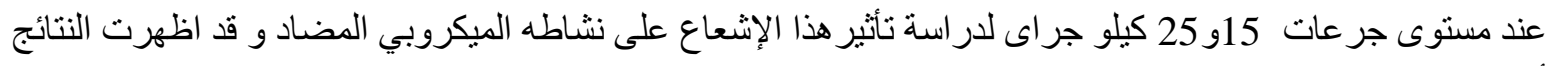

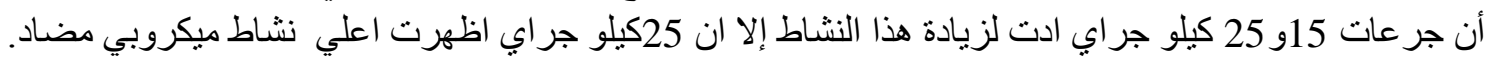

